\title{
ANALYSIS OF MAGNUM ADVERTISEMENTS IN THE CONTEXT OF SEMIOLOGY FROM THE PERSPECTIVE OF GLOBALIZATION: “HEDONISM AND ITS ICECREAM FORM”
}

\author{
Ali Ulvi ÖZBEY ${ }^{1}$ \\ Zekiye TAN $^{2}$
}

\begin{abstract}
Globalization shows its effect neorly all around the world. Advertising is one of these fields. While advertising is responsible for explaining the characteristics of a product, global world advertising does different thing. The individual wants to show satisfaction with the product he needs. By using this stragety, brands give individuals not only brand but also emotions wanted. While advertisers present the product, they can do this accoding to the condition of the crociety. Unlike many brands that advertise on topicality, Magnum deals with the issues of more globalization. Magnum uses the realites of global world such as the vanily of consumption, the body of women as materiel Since it is seen that ads have different languages, semiotics analysis can reveal these differences. In this study, some concepts will be explained at the beginning, their interrelations will be examined and semiotics will be analyzed.
\end{abstract}

Keywords: Globalization, Semiotics, Brand, Pleasure, Magnum

\footnotetext{
${ }^{1}$ Dr. Öğr. Üyesi. Bingöl Üniversitesi. auozbey@bingol.edu.tr. ORCID:0000-0002-7880-8312.

2 1zek2.tan@gmail.com. ORCID: 0000-001-6552-2641

DOI: 10.33464 /dorduncukuvvet.628757

Makale Gönderim Tarihi: 03.04.2019 - Makale Kabul Tarihi: 26.11.2019
} 


\section{MAGNUM REKLAMLARININ KÜRESELLEŞME PERSPEKTIFINDEN GÖSTERGEBİLIM BAĞLAMINDA ANALİİ: "HAZ VE HAZIN DONDURMA HALİ"}

\section{Özet}

Küreselleșme, dünya genelinde birçok mecrada etkisini göstermiștir. Bu alanlardan biri de reklamcılıktır. Reklam, bir ürünün özelliklerini anlatmakla yükümlüyken küresel dünya reklamcılığı bunun dışına taşımıştır. Birey ihtiyaç duyduğu ürünle beraber statü, gösteriş, tatmin olmak istemektedir. Markalar bu stratejiyi kullanark bireylere sadece markayı değil bununla beraber bazı istenilen duygularıda verir. Reklamcılar ürünü sunarken o toplumun durumuna göre veya daha küresel ölçekte bunu yapabiliyorlar. Yerellik üzerine tanıtım yapan bir çok markanın aksine magnum daha küreselleşmenin beraberinde getirdiği konuları kullanmaktadır. Magnum gösteriş tüketimi, kadın bedeni gibi küresel dünyanın gerçeklerini materyal olarak kullanmıştır. Bu şekilde bakıldığında reklamların farklı dillerinin olduğu görüldüğünden göstergebilim analizi bu farklılıkları açığa çıkarabilmektedir. Bu çalışmada da başlangıçta bazı kavramlar açıklanıp, bunların karşılıklı ilişkileri incelenecek ve göstergebilim analizi yapılacaktır.

Anahtar Kelimeler: Küreselleşme, Göstergebilim, Marka, Haz, Magnum 


\section{Introduction}

Globalization includes many different meanings and definitions. Because the perspective of globalization can often be viewed from an economic perspective, it can often encompass social, technological or religious considerations. According to Sezgin Kızılçelik who is known for its contribution to sociology in Turkey globalization is a disaster for some, a disgrace for some, a misery for some, and a blessing to save humanity from its terrible situation for rest of them(Kızılçelik, 2012b, s. 4).

Nowadays, companies and brands use the power of indicators to take their products one step ahead of others, to increase their permanence in mind and to activate the desire to buy. In this context, customers prefer to have status with symbols that are completely outside their needs. Successful branding, placement of successful icons in cultures, semiotics are becoming more and more important in our world which is experiencing the era of successful visual symbolsIn this case, the importance of analyzing the indicators that surround us becomes clear (Çağlar, 2012, s. 31).Every day and for most of our lives we see and hear many advertisements. Even if you don't read a newspaper or watch television, and walk around the streets with your eyes down, you will find it impossible to avoid some form of publicity, even if it's only a trade display at a local store, uninvited handbills pushed through the letter box or cards displayed in the win- dow of the corner newsagent. We usually take advertisements for granted because they are so pervasive, but many people, not least among them the advertisers themselves, claim that they are one of the most important influences in our lives (Dyer, 2009, s. 2).

The impact that advertising has on people, as well as the millions of dollars spent on it ev- ery year, demonstrates how important advertising is for someone with a message to share or a brand to sell. But advertising does have limitations in its effectiveness. This means that those with a brand or an idea to sell will often need to combine advertising with other messaging tools. We can think of any marketing campaign as an organized plan for stra- tegically using a blend of promotional tools such as public relations and sales promotions (Thorson \& Duffy, 2012, s. 4).

How much can the advertising world benefit from the global world? The result is seen in Magnum ads. With globalization, there have been some changes in many channels. Of course, these changes are not only related to an institution or organization. Individuals have experienced this change at many points. In the capitalist period when everything is needed and hedonism comes to the fore and individuals behave towards it. These situations led individuals to consumption and hedonist behavior. As a result, narcissistic behavior disorder is seen in individuals who are attracted to all things and show curiosity. All these situations caused by globalization can sometimes provide advantages for the advertising world.

Ads have their own transfer method. Some brands prefer a local language, while others prefer the global language. Magnum followed a global process at this point. This glorious passion of life brought by the global world is reflected in its advertisements. Magnum has implemented such a strategy to become a brand in this way. However, this is not the only strategy. He has a strategy in many subjects such as individuals, colors and music he uses in his ads. Examining all this semantic language in advertisements can be done through semiotic analysis. Semiotics, on the other hand, make a meaning inference from the details in general. Semiotics have come to the forefront in 
recent years and it is still a matter of debate whether it is a science or not. They also do not have certain molds that are fully seated.

\section{Aim, Scope and Method of Research}

This study aims to read concepts such as pleasure, consumption and hedonism with the idea of globalization, which is one of the most debated issues of the 21st century, and to read from different perspectives for a better understanding of the subject. The aim of this research is to make semiotic analysis on the topics covered in Magnum advertisements. Research was conducted in Turkey and Turkey also pointed out although not published Magnum ads. Content analysis was conducted on subjects such as subjects, characters, gifts in these advertisements. The 'Magnum' ad was first handled in terms of form and content, then in terms of the impact it had on the television audience and the message it generated. For this purpose, the study of deciphering the Magnum advertising semiology method which was published on various television channels and constituting the database of the study was studied and also the connection between visual and verbal elements was examined.

\section{Semiotics and Advertising}

Semiotics or semiology, is the science that examines the signs and signs in the most general and well-known definition. However, this definition is a definition made according to the subject covered by semiotics. We can also define semiotics according to the method it uses. Accordingly, semiotics is a science that applies linguistic methods to objects and tries to describe everything (games, gestures, facial expressions, religious rituals, literary works, pieces of music...) with language and to explain all non-linguistic phenomena into language metaphors (Dervişcemaloğlu, 2015).

Semiotics is a science that significations human-nature and human-human relations. Human beings considered within the framework of semiotics first understand themselves, the whole life and the whole environment, so that the whole universe becomes meaningful; In the second stage, in order to reveal this meaning, the human being reads himself and his environment by using the passwords created with understanding (Sayın, 2014, s. 51).

Together with these definitions, it is possible to make different definitions about semiotics. Likewise, if we describe very generally, it is necessary to describe meaningful wholes, in other words, indicator systems, to determine the relations that indicators establish with each other, to find the forms of articulation of meanings, to classify indicators and indicator systems, or to explain the interaction between man and man, man and the world. In order to create a comprehensive, coherent and simple theory in terms of epistemological, methodological and descriptive (descriptive), many different studies fall into the field of a science called semiotics in Turkish(Rifat, 2007, s. 48). Semiotics, as it is said in semiotics or English, was introduced as a precursor by the great linguist Ferdinand de Saussure from Geneva about fifty years ago(Barthes, 1993, s. 162). Saussure studied semantics under the name semiotics (Köktürk \& Eyri, 2013, s. 136). The British philosopher John Locke was the first to give its name to semiotics (Erkman, 1987, s. 29). Even though John Locke, who gave its name to semiotics, Ferdinand and Saussure, Louis Hjelmslev, Roland Barthes, Claude Levi-Strauss, Julia Kristeva, Umberto Eco and Thomas 
Sebeok have done important works in this field.

In the field of semiotics, the concept of indicator is an important concept that should be known. In order to comprehend the content of these definitions, it is necessary to put forward what the indicator is the research object of semiotics. The indicator is generally defined as any form, object, phenomenon that represents something outside of itself and is therefore capable of replacing what it represents. In this respect, words, symbols, signs are considered as indicators (Illkdoğan, 2017, s. 3149).

Exactly what semiotics is interested in and what it examines is defined as follows; semiotics examines not only linguistic indicators, but everything that is representative and constitutes a meaningful whole. It can examine all of these indicators in four ways: examines indicators, researches the meaning of indicators, focuses on the use of indicators, focuses on the effects of indicators (Güneş, 2013, s. 334). The function of the indicator is to convey thoughts through declarations. This transmission process comprises an object, that is to say something or a reference, indications, and therefore a uniform transmission means, and of course an emitter and a receiver (Guiraud, 1994, s. 104).

Semiotics has gained importance in recent years. Not only in commercials but also in movies, analysis is made on this issue. Today, there are many materials that constantly draw attention. One of the most important examples of this is the advertisements that appear everywhere in our lives, whether in the virtual world or in posters in daily lives. The messages of advertisers are everywhere. They are on billboards, on the radio, on television, on buses and subways, in magazines and newspapers, on posters, on clothes, shoes, hats, pens - and the list could go on and on. To say that advertising has become a ubiquitous form of textuality in today's 'global culture' is an understatement - it is estimated that the average American is exposed to over 3000 advertisements a day and watches three years' worth of television commercials over the course of a lifetime (Danesi, 2002, s. 177).

The primary function of advertising is to introduce a wide range of con- sumer goods to the public and thus to support the free market economy, but this is clearly not its only role; over the years it has become more and more involved in the manipulation of social values and attitudes, and less concerned with the communication of essential information about goods and services. In this respect it could be argued that advertising nowadays fulfils a function traditionally met by art or religion (Dyer, 2009, s. 1).

Advertising is the announcement of a business, a good or a service for money, in the general broadcasting media, to the public (Ertike, 2009, s. 22). But this is the apparent function. Although the effects of meaning in the world surrounding the human being, the relationships that make up the meaning, are comprehensible or sensible, they are not always clear, distinct, self-addressing, easily observable and indisputable. Meaning does not only consist of what a person who writes or lives, what he says and what he writes, his behavior and reactions to all this. In other words, it is not only what we hear and see, but also the meaning that constitutes the meaning, which is clearly found below, above or beside what is said, lived, observed(R1fat, 2007, s. 15).

The functioning of this advertising text relies on a number of different relationships. There is the 
immediate relationship between the reader of the advertisement, who could be called the advertisee, and the text itself; between the advertisee and the advertiser, who, although they do not meet in person, do interact via the advertising text; between this text and the ones that appear before and after it in the magazine, both articles and advertisements; between the brand, Dolmio, and the consumer; between Dolmio and other competing brands; between human beings and food; between the UK, the country where the adver- tisement is received, and Italy, the country alluded to in the advertise- ment; between mothers and their children; between food shopping and money, and so on (Kelly-Holmes, 2005, s. 2).

Advertising is persuasive in nature. The exact persuasive intent may vary, but the reason the source paid to have that advertisement reach you is either to inform you about something likely to change your behavior (e.g., buy something, quit smoking) or to make you experience emotions that lead you to feel good about a brand or an idea and want to acquire it, learn more, and so on (Thorson \& Duffy, 2012, s. 2).

This is what appears in ads. There is meaning in every detail of the ad. Clothes, characters, music, language, etc. We can find meaning in things. Advertising has its own language. Semiology makes analysis at this point. When people touch the product through the language of advertising, they give meaning to it and thus turn its simple use into a mind experience(Barthes, 1993, s. 166). That's where the innocent aspect comes out. This aspect is what we have not seen. Because even the obvious function of advertising requires a process of meaning: selling things to us above definition. Advertisements should take into account not only the nature and characteristics inherent in the products they are trying to sell, but also the way in which these goods can become meaningful to us (Williamson, 2001, s. 12). So there is simply no meaning. Every detail can also be found in something secret. There are many objects in advertising. The language, clothes, characters, colors used are just a few of them. However, their correct use is more important. It is not possible to use the same strategies in advertisements of every good or service. Research suggests that different strategies are necessary for each good and service. Considering the factors to determine the best strategy and preparing ads in this direction are the conditions for success (Hatipoğlu, 1993, s. 147). Ads should be directly proportional to people's interests. To give an example of a few brands that do this in particular; McDonald's has made practices according to the local characteristics of each culture in which it is part of the principle of becoming as part of the local culture as possible. Menu called Sultan Menu in the month of Ramadan in Turkey and to take part in this menu with pita and dessert is one simple example localized (Ertike, 2009, s. 18), Another brand Snickers ad: ad's success in Turkey has been able to better recognition of the right to use and target audience of the local code (Kaptan, 2015, s. 21) and Coca-Cola is another important example in this point. Cola, who describes herself as a part of Ramadan from the beginning of the advertisement in her ads during Ramadan, addressed to the individual in addition to the cultural dimension and incorporated the information including the different versions of her brand into the advertisement film (Ulusal \& Kalayc1, 2018, s. 65).

Another feature of the ads is the importance of the language it uses. For example, what is the color of a product with commercials in advertising, in general, we can see that the color and tones are dominant. Or the gender and age groups used here are also important. It also uses a future-oriented language in general. The future is discussed in commercials, whereas the moment of reaching the future is constantly postponedSo how can it be believed, or to the extent that it can be credible to 
maintain the effect of advertising. Advertisements are credible because the accuracy of what is said here does not come from the realization of promises, but from the coincidence of the dreams that awaken with the audience's dreams (Berger, 2017, s. 146). In this sense, the advertising technique itself and the way in which the goods or services appear style is an effective element in providing credibility(Güz H. , 2001, s. 24). Semiotics deals with the semantic language of all these hidden details.

\section{Relationship of Globalization and Brand}

Globalization is a process that affects all societies, especially underdeveloped and developing countries (Gelekçi, 2005, s. 268). The capitalist system, known as the previous phase of globalization, is a mode of production that has to be reproduced expanded to exist, survive. The condition of reproduction also forces continuous expansion and expansion. It is necessary to reach and control new resources, to open new markets or to open new markets (Başkaya, 2005, s. 44); therefore it is not surprising that the new market addresses are mostly from third world countries.

According to Giddens, globalization is a process that has a predominant influence on American political and economic power, and is highly unequal (Giddens, 1992, s. 15). Globalization is an extraordinary, enormous and inevitable process for the benefit of all humanity, according to most social scientists who are fed by the capitalist and imperialist system and therefore legitimize the system. Since social scientists, who support globalization, are responsible for the function of not showing its true face, they can put it before humanity as a wonderful thing (K1zilçelik, 2012b, s. $4)$.

There is more than one definition of globalization, which has become a popular concept today. David Harvey's “Time-Space Compression” and Marshall Mclahun's “Global Village” are frequently used definitions. Globalization has an impact all over our lives. From a neighborhood relationship to our shopping, our material and spiritual life can take place in all our lives. However, it does not mean the same meaning to everyone in our lives. For some, globalization is what we cannot be happy without; according to some, the reason for our unhappiness. However, the point where everyone unites is that "globalization is a process that is not both reversible and affects all of us in the same way and in the same way; the world is the fate that cannot escape (Bauman, 2010, s. 7). Globalization has transformed and developed very rapidly. Nowadays, he acts on what people seek and feel missing. Therefore, in the post-capitalist system of risk, concern, uncertainty and insecurity, new needs arise with erosion of trust, loyalty and solidarity in individuals' characters (Sevim, 2015, s. 139). In doing so, the most important strategies are localization strategies. There are many important areas in this regard. However, the adaptation of advertising offers academics in the field of media and communication a productive field for analysis in the field of media, identity, locality and consumer society (Kaptan, 2015, s. 15).

The most important force of globalization in doing all these things is mass media. One of the most important factors affecting and determining the ability of globalization to bring the world closer to each other was the widespread use of internet (Kurt, 2018). People are now living with technology at any moment. TV, virtual world in short everywhere. Ads are fast and tell a lot of things. The meaning in television viewing, which leaves no possibility of stopping and thinking, transforms into a full iconology (Oskay, 2014, s. 95). It does not give individuals the chance to 
think in full. The global world has established its domination over life. The global world creates a living space independent of time and space that takes the place of the social world and manages the physical and mental forms of existence of the human being, introduces them into certain regularities and ensures that they become part of meaningful integrity (Şimşek, 2003, s. 80). This is what David Harvey wanted to say in terms of the metaphor of time-space compression. Time and space have gone beyond their normal meaning. This gives a different impact in the economic context. Bauman's metaphors are idle and tourists. The inhabitants of the first world live in time; space is not important to them because every distance is momentary. The inhabitants of the second world live in space: in a heavy, permanent, untouchable space that captures time and keeps it out of its inhabitants. Their time is empty; nothing happens in their time (Bauman, 2010, s. 92). The concept of time and space related to the economic situation of individuals changes. This is the same in societies. All these results have led to show curiosity in individuals. In this case the brand concept has become popular. Modern people prefer brands rather than practical benefits for reasons such as positioning themselves, adding meaning to the article of use or determining their status (Bıçakçı, 2001, s. 53). Because of their passion for showing off, people take many forms over what they eat, drink and wear. However, they are known and positioned. Therefore, the purpose of show-off occurs in the individual. This pushes the individual to brand products. Brand is a different situation. The product has ceased to be. The brand now has its own characteristics. It's not just a bag or chocolate anymore. Product has many features. Brand is a symbol, identity, need along with its features. Beyond being a name in today's competitive conditions, the brand emerges as a business that adds an identity, personality to the product, shaped by the perceptions of consumers, and guides consumers in product preferences (Can, 2007, s. 225). The product is no longer just needed. The individual requires social status, psychological satisfaction, trust and quality along with the product. In the postmodern culture called transition from production culture to consumption culture, from product culture to brand and image culture, products are consumed symbolically rather than functional characteristics (Aydın, 2004, s. 57). However, being a brand is not an easy process. This requires a correct strategy. The way to create a good brand; good advertising, effective promotion (Ak, 1998, s. 194). The global world and the brand face this point. The global world is powered by technology. The place of technology in brands is important. People now devote a significant part of their days to technology. In addition to good and effective advertising, brands need to follow it with the right strategy. Technology holds an important place here. Continuous tablet, TV, phone and so on. everywhere. This situation does not give a chance to escape. Individuals may have problems with the situation of trust in the products. In particular, today's technological development brought with it, communication and transportation spaces, the presence of more than one kind of the same product in the market, has led to the increase of selfservice sales units. In addition, because many products are sold in packages, the consumer has no chance of touching, tasting or trying(Can, 2007, s. 226). When this happens, individuals receive the product they know. With the development of production technologies, the proliferation of product alternatives, businesses try different strategies to create brand loyalty by creating an emotional connection with the consumer (Doğaner \& Armağan, 2019, s. 715).

In today's intense competition market, their experiences with consumers and brands have become an important concept, and every positive communication with brands has resulted in trust, satisfaction and positive results for the sector. As a result, loyalty towards brands has been realized (Çetin, 2017, s. 475). The global world demands confidence, commitment, quality, status, 
satisfaction, and so on. After a while the products that can give them as a brand, as well as features as an identity comes out.

\section{The concept of pleasure in terms of individual and social}

Pleasure is a state of spiritual satisfaction. This can be felt when shopping, in a beautiful landscape, while smoking a cigarette. This concept, which corresponds to hedonism, is known with Aristippos and Epicurus in antiquity. This concept, defined very differently, has two invariants. It can conjure up things that are pleasant and different things for everyone. While pleasure does not evoke the same things for every individual, is there a common situation for everyone? We can say that the consumer society can afford it (Hatun, 2012). Hedonic behavior is seen in individuals in these societies. Hedonic behavior, as a psychological phenomenon, is a pleasant emotion arising from having the things that individuals like and has important effects on consumer behavior (Meydan \& Tunca, 2018, s. 841).

In today's society under the influence of postmodernism, individuals live a pleasure-oriented life and shape their lives in this direction(Deniz, 2019, s. 101). The products are no longer needed, but they can also give emotions that come with capitalist life or gain a different dimension. Some people who are approaching from an emotional point of view can do shopping not only by using a utilitarian understanding but also for pleasure. According to this understanding, which is also expressed in the literature as a hedonic consumption habit, people make purchases in order to follow fashion, to establish social relations, to relax or to make others happy (Şengün \& Karahan, 2013, s. 15). The consumer buys an athletic body instead of yogurt, nobility instead of shoes, automobile power and freedom, and power instead of hours (Aydın, 2004, s. 56).

The concept of global culture is related to a particular lifestyle based on consumer culture. The artificial needs caused by the consumption culture lead to the impression that global culture is surface and external. There is a complete contradiction between the hegemony of civilization hidden by the concept of global culture and the coexistence of civilizations. The homogenization of global culture is based on the standardization of consumer culture rather than the acceptance of universal human values resulting from the accumulated experience of all civilizations (Ardıç \& Özcan, 2012, s. 33).

Individuals can get rid of the unhappiness and troubles of their busy lives by consuming something. The main reason why individuals try different identity masks in the market is the desire to get rid of daily problems and problems, albeit temporarily. This is a conscious attempt by the market to maintain and dominate the capitalist system upon which consumption is built. The point that individuals miss here is that they strengthen capitalism in doing so. While individuals are feeling this pleasure, they give great support to consumption. The fact that the consumed things are done in order to give pleasure other than the necessity enables the consumption society to strengthen in capitalism as well(Özcan, 2007, s. 144).

\section{On the relationship between pleasure, hedonism and narcissism}

Hedonism aims to get pleasure in every part of life. This can lead to hedonist behavior in individuals and the narcissistic behavior that results from this. These hedonist behaviors seen in 
individuals today have led to the efforts of individuals to take pleasure in every aspect of their lives. The individual who wants to enjoy everything from family life to business life will want it. He will try to get pleasure from every situation he is in. This will lead to the emergence of narcissistic behavior individuals who only think about themselves. So what is this pleasure, hedonism and narcissism? How exactly do they relate? Hedonism is the behavior that wants to constantly repeat the pleasure of consumption or shopping (Özdemir \& Yaman, 2007, s. 81). Pleasure is pleasant. Hedonism says that the principle of pleasure should be placed all over life. Hedonists argue that life should be planned in a way that gives pleasure.

The concept of narcissism comes from Narcissus, who fell in love with himself in Greek mythology by seeing the contrary in water and consumed his life by following this lover whom he could never reach(Yurdakul \& Bostanc1, 2016, s. 110). Narcissus was so fascinated by himself that it caused his own death. Narcissism is a state of admiration and self-esteem. This feeling is very exaggerated and dangerous. Especially in recent years, narcissistic disorder has increased with social media. Individuals who share each form have become more and more fascinated by the feedback they receive. Although narcissism is one of the oldest phenomena in the history of science, interest in narcissism has increased in recent years thanks to researches aimed at understanding the relationships between various organizational variables(Gürer \& Çiftçi, 2019, s. 81).

On the other hand, although narcissism is popular as a label, it is difficult to find scientifically verified information about narcissism, except for academic journal articles. Many websites about narcissism; it is based on a combination of assumptions, personal experiences, and poorly understood psychoanalytic theories (Twenge \& Campbell, 2015, s. 184).

\section{The Importance of Advertising on the Way from Brand to Branding}

Brand is the name given to the names that distinguish the goods and services of your business from other businesses. Brand names do not have any rules at the time of creation. You can create the letters you want, or the ones you think are more appropriate, by bringing the numbers or combinations together(Plazacubes, 2018). One brand can be mixed with other brands. Today, with the development of mass communication, people are exposed to a lot of messages every day and in this context, it is difficult for them to distinguish between companies that produce similar products and services (Lembet, 2018, s. 2). This makes recognition even more difficult. In this process, these companies make great efforts to brand. This process has not been so short and easy. Branding has an identity of the product. The right strategies should be used. One of the most important steps at this point is advertising. In order to achieve success in the extent that marketing focuses on the promotion of products / services to target audiences, it should also be focused on developing a corporate-oriented corporate marketing perspective such as the culture of the organization, management philosophy, interpretation of events and manner of behavior, employee behavior styles, and internal and external communication approach (Yeygel \& Yakin, 2007, s. 102). Hence advertising should be the most effective, and accurate way. Attention should be paid to the feelings of society in advertising. The right strategy has been an important step for branding. 


\section{Parallelism with Magnum Ice Cream and Globalization}

Globalization has affected many fields as well as advertising. There is hardly a single medium in the developing world where we cannot see the impact of globalization. A large area has been formed within the advertising field. It has been easier to reach the desired audience in the global world. But reaching the audience is not enough. Individuals no longer want a product but a status and satisfaction with it. Correct and effective advertising in this way is very important. Advertising is obliged to provide information about the product.Ancak verlen bilgi kadar nasıl verildiği de önemlidir. However, the information given is as important as how it is given. Body project is very important in consumer culture. The culture of globalization is based on the pleasure of the body (Kızılçelik, Küreselleşme, Beden ve Şizofreni, 2003, s. 38). This period is expected from the individual to be clean, beautiful and weak. It is no coincidence that gyms and beauty centers have been used so much in recent years. They have used this in advertising. So advertisements are made in which the female body is commodified and turned into an object of pleasure (Demir \& Yiğit, 2013, s. 459).Magnum ad is one of those who use it in their ads. They work with individuals who are in line with today's understanding of beauty.

The consumer society also uses the show-off curiosity, which is a common situation, as a material for Magnum itself. Fancy is an important place for people. The pretentious consumption, like some other needs, is made not only to satisfy one's self but to gain value in the eyes of others. Although the person's character, psychological structure plays an important role in the direction of such consumption, the most important factor that cannot be rejected is the cultural values of the society. The attitude of the society towards the curiosity of the cultural and social structure of the society will direct one's behavior (Babaoğul \& Buğday, 2012, s. 145). These situations push individuals to brands a little more. Taking advantage of this situation, the Magnum brand has skillfully used it in the commercials brought by the global world. In her commercials she uses a combination of women and pretension.

While sometimes adopting a "universal" communication in the visual or linguistic messages of the advertising message, it sometimes prefers to construct messages specific to the society and the community where the advertising message will be published (Güz \& Küçükerdogan, 2005, s. 65)Unlike brands likeCoca-Cola and Snickers; Magnum, has used a more universal strategy. In the westernizing world, many emotions have been formed all over the world. They can do this especially through mass media. People from different religions and languages can unite for a topic in social media. Magnum advertise through them.

\section{Factors that make Magnum valuable}

Capital, which sees itself as the sole condition of globalization, has been forced to place its essence to produce and market, and has become visible to transnational corporations under different names and guises as a response to real or imaginary local differences (Dirlik, 2012, s. 98); in this sense, Magnum is a brand that is aware of the global world.

Globalization has been influenced by many channels in many parts of the world. Different religions, languages and cultures have created common feelings among people. Individuals who enjoy pleasure, individuals who are caught in pretentious consumption are examples of this. The global world has made the individual feel all this as a need Individuals have been exhibiting narcissistic behaviors that enjoy every moment of being liked. In this way, unlike many brands, 
Magnum preferred to use a global language instead of a local languageWhile doing this, they did not present it on women using only body strategy. It has used trans and lesbian individuals in his commercials. In this way, they addressed individuals with different sexual preferences. Magnum used a combination of ostentatious consumption and female body. Magnum also did this through his privileged class. With the consumption of pretension, there was a desire to be appreciated. Magnum, which is aware of this, constitutes the advertising agenda through the privileged, elite segment. For this reason, Magnum has worked with individuals who are in line with the understanding of beauty brought by capitalism. In all of this show, there are individuals who enjoy the magnumMagnum is shown as the greatest part of life. Therefore, Magnum woman or man attracted attention in the environment, has been shown as admired individuals. That's what makes magnum worth. Using a global language, it gives people the emotions they want alongside an ice cream.

\section{On Processing Magnum And Pleasure}

Together with globalization, hedonism stands out for the enjoyment of everything in the life of the individual. Individuals started to exhibit hedonist behaviors in this process. These individuals, who exhibit hedonistic behavior, are over the course of a show curiosity. Consumers are no longer needed and become an object of pleasure. The global world has been a subject for all of these Magnum ads they bring. Magnum advertisements also covered the issues of this globalization. The idea of pleasure is more than enough. Magnum was more of a pretension product than an ice cream. Magnum, which mentions pleasure in its slogan, is adorned with individuals receiving continuous magnum pleasure.

\section{Space and Character Analysis in Magnum Advertisements}

Magnum, who places great importance on display in its advertisements, acts in this direction in the spaces and characters it chooses. Elite spaces are used, where elite are located. This can be an entertainment venue, a hotel or a flashy house. Places are usually large and showy.

In character selection, individuals who are in line with capitalist beauty are used. Usually the woman uses her body. He has a Magnum understanding of women, and they are powerful women with beautiful, bold looks, who get everything they want, admire everyone. Well-known celebrity names are also used. Some of those; Bella Hadid, Alexander Wang, Ajda Pekkan, Orlando Bloom and Yasemin Özilhan. The notable side of advertisements played by prominent names draws attention on the remarkable aspects of these names. While Bella Hadid completed her beauty with Magnum, Ajda Pekkan pointed out her success. In addition, as Magnum women and Magnum men in these ads they play as Magnum' a little more charm, beauty, show off.

\section{Semiological Analysis of Magnum Ads}

Unlike many brands, Magnum has promoted globally. It has used many points such as the ostentatious consumption brought by globalization, the understanding of beauty and the use of the female body. First of all, according to the most prominent female figures in their advertisements, women with noble and strong stance are used. In addition, Magnum creates a woman-shaped thought. This woman is described in an ad starring Orlando Bloom. In the Orlando Bloom 
commercial, Magnum portrays that he is very different to the woman Magnum asked. The woman she describes is a beautiful, intelligent, attractive and audacious woman. In the ad, the woman asking the question to Orlando Bloom says that Magnum is smart, beautiful, attractive and if she is in pursuit of pleasure, she gets what she wants. Here, the privilege of being a Magnum woman is emphasized. In another commercial, Ajda Pekkan, who will appear at the concert, completes every success and beauty in her life with Magnum. Shee says she's a Magnum woman with all his success. Magnum pointed out the importance of women.

Magnum can present the concept of pleasure by creating an image of sexuality. There is a wild animal beside women in this advertisement depicting women who eat magnum. These animals with Magnum-eating women can be interpreted as the states that gave them strength beside their beauties. There are men affected by these women. But women seem inaccessible. At the end of the ad, a Magnum man appears and gets close to the Magnum woman. The lions next to them both get closer. A message saying 'release you inside' appears on the screen and says 'Magnum full of pleasure' in the promotional part of the ad. Unlike these two, which remain silent before the end of the ad, high-tone roaring lions are shown. These lions, depicting the states of magnum eaters, show the pleasure in them. They remain silent even though they are influenced by each other, the lions roar and express their emotions. Magnum here can be said that the emotions that the duo have to release are sexuality, from the roaring lions and the most delightful Magnum slogan. Bella Hadid's ads is an example of this. In this commercial, Bella Hadid prepares Alexander Wang to shoot and makes the final touch. Bella Hadid takes the Magnum in her purse and comes across the camera with it. It is shown as a piece that complements the beauty of Magnum. Seeing Bella eating ice cream, Alexander Wang takes one and passes it in front of the camera. At the end of the commercial, Alexander Wang puts all the ice cream in his mouth and poses with Bella Hadid in strange poses. The ad is a bit ecstatic like a couple and draws attention to sexuality once more. In addition to the slogan if you are after the pleasure, Magnum does not only treat the pleasure. In an ad where a woman hurts her wrist, the man carries the woman to her car. He hands the woman an ice cream and drops ice on her wrist. The woman gets out of her car in a recovered way, and the man gives a glimpse of what she likes. After the slogan is over, the duo's bold and contented gaze shows that the situation is more than Magnum's pleasure.

Magnum mini advertisements include women who wearily throw themselves into the house. The first place they come home is Magnum' closet. In one commercial, there is a woman who is tired at home and a man is waiting for her. The woman takes off her jacket and the man does it in front of her. Then 'the pleasure of coming home is another' she says. Man approaches woman. While giving an image of sexuality, the woman passes by the man and turns to Magnum. In another advertisement, the tired woman came across a house that was moved in front of the apartment. However, she climbed on top of things and went through the window of her house and bites Magnum out of her closet. In the next frame, 'nothing can prevent you from reaching the Magnum Mini Classic.' says. Magnum can be interpreted as giving the impression that it meets them in today's world where mini-ads are constantly running around and individuals trying to enjoy everything.

It is seen that pleasure is processed in a way that attracts more attention in magnums with luxury car gifts. After bite the ice-cream in two different commercials, these women often bite their lips looking at the camera and daring. Both advertisements show that after eating ice cream in these 
places that give the atmosphere of the Magnum factory they entered, they were in the car in the second part of the advertisement. There are two car gifts, only the person in the other car is not shown. These two women compete in the car next door, and in Magnum commercials, which are often unspoken, the women shout with great pleasure. In these advertisements, Magnum's pleasure is shown to be doubled by cars. It can be interpreted that two cars are given and only the person in a single car is represented, the Magnum pleasure is doubled and the happiness of this pleasure is represented in a single car representing the ordinaryness before Magnum.

Magnum doesn't always commit to the admiring woman when she's in her flashy life. Such a woman is admired in a normal life. The woman who did not get into her car at the beginning of the ad, skateboarding around the city. In the lyrics of the song 'you everywhere, pleasure everywhere' says. When she goes out of the show, she becomes a woman who enjoys everything. In addition, from the beginning to the end of the ad, everyone looked at the woman admiringly. After touring the whole city, after returning to a flashy party, people around him watch with admiration. Magnum here pointed out that being Magnum woman, being privileged everywhere. In the lyrics of the song, it can be interpreted that pleasure is the place of Magnum because the woman will not notice.

Magnum also appeals to all segments. It attracts LGBT individuals in their ads. The advertisement, played by transgender individuals, shows women with only visible legs. All of these individuals are located in separate but quite elite spacesThen all of them start to return to the screen and have gotten too daring looks. We also understand that no one looks at the places they are in, from the masked people around the trans person in the party. And at the end of the advertisement, the person with a red umbrella in his hand leaves the umbrella and opens his hand in a free stance under the pouring rain. Surprisingly, in the advertising of lesbian individuals, this situation is not noticed until half of the advertisement. Then the bride on her father's arm sent her to her husband and the other woman in a wedding dress came to the screen with a smile. Marriage was minced. At the end of the advertisement, they have Magnum bites and they laugh. Magnum can be interpreted in these advertisements as ways of saying that they are with LGBT individuals.

\section{Conclusion}

Today, people live in a passion for show. They want everything they consume to give them an image. Moreover, in this process where hedonist behavior is seen too much, the individual is not only looking for need from everything he consumes. Consumed 'thing' time, house, car does not matter. What they feel is more important to the individual. Therefore, materialism is becoming an important concept at this point. Like many aspects of hedonism and narcissism, materialism harms others and society. On average, materialist people are more unhappy and more depressed. Only people who want to have more money suffer from mental health deterioration (Twenge \& Campbell, 2015).

The capitalist world initially introduced everything as a need. Afterwards, he emphasized the importance of having to take pleasure from them. Globalization, defined as the last stage of capitalism, whose influence we see almost everywhere, has succeeded in bringing the epidemic of pleasure in today's world to all over the world through advertising.Bir ürünü seçerken bunun 
vereceği tatminlikle ilgilenen bireyler olmuşlardır. There are individuals who are more interested in the satisfaction of choosing a product than its utility. This has paved the way for branding.

The point that separates the product and the brand is not only the product that is needed but the other one gives the satisfaction to the individual. For example; Magnum is no longer just an ice cream. It has become a product that gives a status that gives pleasure and showy. Brands are generally known by their names, not the product they are. The process of becoming a brand is a long process. In this process, effective advertising is becoming a step towards. These advertisements, which appear in many parts of our lives, use strategy while presenting the product.

Magnum generally uses some of the situations brought by globality. Advertisements give important issues behind what they appear. Magnum not only features the ice cream, but also includes some of the emotions needed today. These details in advertisements are analyzed through semiotics analysis. A semantic information is given by following every detail in many fields of semiotics. In the semiology analysis of Magnum ads, many details have been examined. He used it in every detail of his magnum ads, which preferred a global language.

As a result, in this study, we tried to analyze the language of advertisements as semiotic and express the main messages behind the magnum brand. As stated throughout the study, advertisements can be seen as a strategy of facilitating intake with key words that will place in people's minds rather than promotion. 


\section{Kaynakça}

Ak, M. (1998). Marka Yaratımında Taklitçilik, Doğru, Etkili Reklam ve Marka İmajı. İletişim fakültesi dergisi, 193-202.

Ardıç, N., \& Özcan, S. A. (2012). Küyerel Dönüşümler: Küreselleşme, Zihniyet, Siyaset. İstanbul: Küre Yayınları.

Aydın, D. (2004). Marka Konumlandırma ve Sembolik Tüketim İlişkisi. Selçuk Üniversilesi Edebiyat Fakültesi Dergisi, 55-70.

Babaoğul, M., \& Buğday, E. B. (2012). Gösteriş Tüketimine Karş1 Gönüllü Sadelik. Tüketici Yazıları (III) (s. 76-87). içinde Ankara: Elma Teknik Basım.

Barthes, R. (1993). Göstergebilimsel serüven. İstanbul: Ypı Kredi Yayınları.

Başkaya, F. (2005). Küreselleşmenin Karanlık Bilançosu. Ankara: Özgür Üniversite Kitaplığı.

Bauman, Z. (2010). Küreselleşme Toplumsal Sonuçları. İstanbul : Ayrıntı Yayınları.

Berger, J. (2017). Görme Biçimleri . İstanbul: Metis Yayınları.

Bıçakçı, İ. (2001). İletişim Dünyamız. Ankara: MediaCat Kitapları.

Can, E. (2007). Marka ve Marka Yapılandırma. İI.I.B.F. Dergisi, 225-237.

Cihangiroğlu, N., Teke, A., Uzuntarla, Y., \& Uğrak, U. (2015). Narsist Kişilik Eğilimleri ile Kuramsal Bağlılık Düzeyleri Arasındaki İlişkinin Analizleri. Yönetim ve Ekonomi Araştırmaları Dergisi, 1-18.

Çağlar, B. (2012). Bir İletişim Biçimi Olarak Göstergebilim. LAÜ Sosyal Bilimler Dergisi, 22-34.

Çetin, K. (2017). Marka Deneyiminin Güven, Tatmin ve Bağlılığa Etkisi. Bilecik Şeyh Edebali

Üniversitesi Sosyal Bilimler Enstitüsü Dergisi, 475-492.

Danesi, M. (2002). Understanding Media Semiotics. New York: Arnold Publisher.

Demir, N. K., \& Yiğit, Z. (2013). Reklam Fotoğraflarında Kadın Bedeninin Değişimi. International Periodical For The Languages, Literature and History of Turkish or Turkic, 459-472.

Deneçli, C. (2013). Küresel Markalar, Yerellik Ve Kültürel Göstergeler. The Turkish Online Journal of Design, 1-11.

Deniz, A. K. (2019). Dijital Çağın Hedonist Çalışanları: Dijital Göçebeler. IBAD Sosyal Bilimler Dergisi, 101-113.

Dervişcemaloğlu, B. (2015). Göstergebilim. Göstergebilim tanımı, 1.

Dirlik, A. (2012). Küreselleşmenin Sonu mu? İstanbul: Ayrıntı Yayınları.

Doğaner, M. C., \& Armağan, E. (2019). Sanal Marka Toplulukları ve Marka Sadakati: Nikon Örneği.

Íktisadi ve İdari Bilimler Dergisi, 715-735.

Dyer, G. (2009). Advertising As Communication. London: Routledge.

Erkman, F. (1987). Göstergebilime Giriş. İstanbul: Alan Yayıncılık.

Ertekin, Y., \& Yurtsever, G. (2001). Yönetimde Narsizm Üzerine Bir Deneme. Amme İdaresi Dergisi, 3746.

Ertike, A. S. (2009). REKLAM. ANKARA: Detay Yayınc1lik. 
Gelekçi, C. (2005). Küreselleşme-Yerelleşme İlişkisi. İstanbul Üniversitesi Sosyoloji Konferansları Dergisi, 263-277.

Giddens, A. (1992). Modernliğin Sonuçları. İstanbul: Ayrıntı Yayınlan.

Guiraud, P. (1994). Göstergebilim. (M. Yalçın, Çev.) Ankara: İmge Kitabevi.

Güneş, A. (2013). Göstergebilim Tarihi. E-Journal of New World Seciences Academy, 332-348.

Gürer, A., \& Çiftçi, G. E. (2019). Narsizmin İş Doyumu ve Bireysel Performans Üzerindeki Etkisi

Üzerine Bir Alan Araştırması. OPUS Uluslararası Toplum Araştırmaları Dergisi, 78-103.

Güz, H. (2001). Reklam Stratejisi ve Reklam stratejisini Etkileyen Unsurlar. Journal Of Selçuk Communucation, 20-28.

Güz, N., \& Küçükerdogan, R. (2005). Göstergekllreler. Reklam ve "Öteki" Kavramı. Journal of istanbul Kültür University, 65-73.

Hatipoğlu, Z. (1993). Temel Pazarlama. İstanbul .

Hatun, Ş. (2012, 03 07). Haz Biyolojisi, Tüketim Toplumu, Obetize ve Çocukların Korunması 07 22, 2019 tarihinde https://www.birikimdergisi.com: https://www.birikimdergisi.com/guncel-yazilar/606/hazbiyolojisi-tuketim-toplumu-obetize-ve-cocuklarin-korunmasi\#.XVM5GOMzbIV adresinden alınd1 İlkdoğan, H. (2017). Göstergenin Toplum Düzlemindeki Yeri: Toplumsal Göstergebilim. İdil Dergisi, 3147-3164.

Kaptan, Y. (2015). Küresellik ve Yerellik Arasında Reklam Adaptasyonları: Snickers Örneği. İlef Dergisi, 13-33.

Kelly-Holmes, H. (2005). Advertising as Multilingual Communication. New York: Palgrave Macmillan.

Kızılçelik, S. (2003). Küreselleşme, Beden ve Şizofreni. C. Ü. Tip Fakültesi Dergisi, 89-94.

Kızılçelik, S. (2012). Küreselleşme ve Sosyal Bilimler. Ankara : Anı Yayıncılık.

Köktürk, Ş., \& Eyri, S. (2013). Dilbilim ve Göstergebilim: Ferdinand De Saussure ve Göstergebilimi Anlamak. SAÜ Fen Edebiyat Dergisi, 136.

Kurt, Ü. (2018). Küreselleşme ve ekonomik kompleksite ilişkisi: Türkiye örneği. Hitit Üniversitesi Sosyal Bilimler Enstitüsü Dergisi.

Lembet, Z. (2018). MARKALAR VE KURUMSAL SOSYAL SORUMLULUK Markalar ve Kurumsal Sosyal Sorumluluk. Hacettepe Üniverstesi Sosyolojik Araştırmalar E-Dergisi, 1-24.

Meydan, B., \& Tunca, M. Z. (2018). Sosyal Medyanın Hedonik Satın Alma Davranışlarına Etkileri Üzerine Bir Araştırma. Mehmet Akif Ersoy Üniversitesi Sosyal Bilimler Enstitüsü Dergisi, 832-854.

Oskay, Ü. (2014). Çă̆daş Fantazya. İistanbul: Der Yayınevi.

Özcan, B. (2007). Hedonizm ve Kimlik Temeline Dayalı Postmodern Tüketim Yaklaşımı. Sosyoloji Konferanslart Dergisi, 119-130.

Özdemir, Ş., \& Yaman, F. (2007). Hedonik Alışverişin Cinsiyete Göre Farklılaşması Üzerine Bir Araştırma . Eskişehir Osmangazi Üniversitesi İIBF Dergisi, 81-91. 
Plazacubes. (2018, 03 12). Marka ve Markalaşma Nedir? Ne Değildir? 07 25, 2019 tarihinde https://www.plazacubes.com: https://www.plazacubes.com/blog/marka-nedir-markalasma-nedir/ adresinden alınd 1

Rıfat, M. (2007). Homo Semioticus ve Genel Göstergebilim Sorunları. İstanbul: Yapı Kredi Yayınları.

Sayın, Ö. (2014). Göstergebilim ve Sosyoloji. Ankara: Anı Yayınc1lık.

Sevim, B. A. (2015). Postkapitalist Dönemde Küresel Markaların Yeni Pazarlama Stratejisi:

Kitlelerin Yeni Yaşam Koçu Olarak Coca Cola. Uluslararası İktisadi ve İdari İncelemeler Dergisi , 135-156.

Şengün, H. İ., \& Karahan, M. (2013). Hedonik (Hazcı) Tüketim Alışkanlıkları ve Tüketicileri bu Tür Alışkanlıklara Motive Eden Nedenler. Dicle Üniversitesi İktisadi ve İdari Bilimler Fakültesi Dergisi, 13-26.

Şimşek, S. (2003). Emperyalizmin Küreselleşme Boyutunda Modernleşme Sürecine Etkileri ve Kitle İletişim Araçlarının Emperyalist Düşünceler ve İmajların Yayılış Sürecindeki Fonksiyonları. Journal of Selçuk Communication, 76-83.

Thorson, E., \& Duffy, M. (2012). Marketing Communication at Work. South Western: South-Western Cengage Learning. Twenge, J. M., \& Campbell, W. (2015). Asrın Vebası Narsisizm İlleti. İstanbul: Kaknüs Yayınlar1.

Ulusal, D., \& Kalaycı, B. (2018). Göstergebilimsel Açıdan Coca Cola Ramazan Reklamının Çözümlenmesi. Uluslararası Sosyal Bilimler Dergisi, 62-67.

Williamson, J. (2001). Reklamların Dili. Ankara: Ütopya Yayınları.

Yeygel, S., \& Yakın, M. (2007). Kurumsal Reklamlarda Göstergeler Aracılığıyla Marka Kimliğinin İletilmesi. Selçuk İletişim, 102-117.

Yurdakul, A., \& Bostanc1, A. B. (2016). Öğretmenlerin Okulların Örgütsel Narsizm Düzeylerine Yönelik Görüşleri ile Özyeterlilik Algıları Arasındaki İlişki. Kırıkkale Üniversitesi Sosyal Bilimler Dergisi, 109-126. 